\title{
GEOGRAFIESE INVLOEDE OP ONS BESKAWINGSPATROON
}

Die opskrif van hierdie lesing lui: „Geografiese invloede op die Suid-Afrikaanse Beskawingspatroon". Onmiddellik laat dit die vraag ontstaan wat 'n geografiese invloed nou eintlik is: hoe word dit onderskei van bv. 'n geologiese of sê maar 'n plantkundige invloed, en is daar nou werklik iets soos 'n geografiese invloed? Met 'n lang bespreking van hierdie vrae wil ek u nie oorval nie: laat my volstaan met die verklaring dat ek vir die doeleindes van hierdie beskouing uitgegaan het van die standpunt dat die geografie die verhouding bestudeer tussen die mens en sy omgewing en dat ek as geografiese invloede geneem het alle invloede wat kan uitgaan van die fisiese omgewing in die breedste sin van die woord.

Maar as ek die woorde "geografiese invloede" breed vertolk het, wil ek terselfdertyd u verlof vra om die woorde „SuidAfrikaanse beskawingspatroon" eng te vertolk. Soos aanstons sal blyk, is die verhouding tussen 'n omgewing en verskillende beskawingspatrone verskillend. As ' $n$ mens nou ' $n$ beskawingspatroon vir elke rassegroep in Suid-Afrika sou moes bepaal en die omgewingsinvloede op elkeen van die beskawingspatrone sou moes beskryf, sou hierdie voordrag amper tot in die oneindige verleng kon word. Daarom wil ek my vandag bepaal by slegs een beskawingspatroon in Suid-Afrika, naamlik dié van die blanke bevolking van die land. En selfs daar vra ek u verlof om te veralgemeen - om nie te onderskei tussen die variasies in die blanke beskawingspatroon soos dit voorkom by die Afrikaanse, die Engelse, die Griekse, die Portugese, die Joodse en al die ander bevolkingsdele nie.

Die vraag of daar invloed van die omgewing uitgaan op die mense wat daarop beweeg en wat die aard van daardie invloed is indien dit bestaan, geniet lank reeds die aandag. Volledige eenstemmigheid oor die saak is nie verkry nie en menings wissel van die uiterste determinisme soos verteenwoordig deur die Fransman Demolins (wat nie huiwer om te verklaar dat as die geskiedenis van die mensdom weer sou moes begin en die aardoppervlak onveranderd sou gewees het, daardie geskiedenis in sy hooftrekke herhaal sou word nie) (1) tot die houding van iemand soos Arnold Toynbee wat sê dat die wisselwerking tussen menslike en omgewingsfaktore nooit 
voorspel sal kan word nie omdat die reaksie van die akteurs, die psigologiese moment, onmoontlik wetenskaplik vooruit geraam kan word (2: 67).

Oor die feit dat daar wel 'n besliste verhouding tussen omgewing en die bewoners van die omgewing is, is daar egter blykbaar weinig meningsverskil. John Phillips stel dit baie mooi waar hy sê: „The environment - or habitat - is the stage on which life has its being, plays its part... and thus inevitably is itself influenced by the actors. In turn, a change in habitat induces a change in the community of actors..." (3: 31). Dit is dus nie oor die feit dat daar 'n verhouding tussen omgewing en die bewoners van die omgewing bestaan dat daar meningsverskil is nie, maar wel oor die aard van daardie verhouding.

Vir my klink dic standpunt van Ryan heel logies en eenvoudig as hy verklaar dat alle menslike bedrywighede primêr plaasvind in antwoord op die begeerte om menslike behoeftes en begeertes te bevredig en nie op grond van die beherende invloed van die omgewing nie. Dit begin by die behoefte aan voèdsel, skuiling en kleding, en daarna volg die ander minder dringende begeertes na politieke instellings, ontspanningsgeriewe en die bevrediging van die estetiese gevoel. En, sê Ryan, in hierdie strewe wysig die mens sy natuurlike omgewing en word hy weer op sy beurt deur sy natuurlike omgewing verander (4: 12).

Hierdie veranderingsproses is waarskynlik ook nie net tot die mens se brein- en spierkrag beperk nie. Hyams sê in sy stimulerende werk dat die karakters van mense buigbaarder is as hul spiere en dat dit ' $n$ erkende feit is dat mense wat ' $n$ moeilike bestaan op ' $n$ arm bodem voer soos die wingerde in soortgelyke toestande 'n delikater en meer stimulerende geur adem as die bewoners van die ryk dele van die aarde. Die maniere van die moeras- en bergbewoners is soms ru, maar dit lyk of hulle hulle edeler gedra as hul bure in die ryk valleie, sê hy (5: 115).

Of dit nou so is dat mense se karakter deur die omgewing beïnvloed kan word of nie, daar bestaan blykens bostaande ' $n$ invloedryke volume van deskundige oortuiging dat daar ' $n$ besliste invloed van die omgewing op die mens en die verwesenliking van sy begeertes uitgaan. En aangesien dit juis in 
die verwesenliking van sy begeertes is dat die mens gestalte gee aan sy beskawingspatroon, kan met vrymoedigheid verklaar word dat die omgewing en die beskawingspatroon nie los van mekaar staan nie.

Dit bring ons by die ontplooiing van die mens se beskawingspatroon. Tradisioneel word aanvaar - en dit lyk asof argeologiese bevindinge dit wil bevestig, hoewel prof. Raymond Dart 'n ander standpunt inneem - dat die steentydperk-mens geleidelik van 'n paleolitiese jag- en trekkultuur gevorder het tot ' $n$ neolitiese akkerboukultuur en uiteindelik 'n sintese van die twee (6:10). In daardie tydvak is waarskynlik gebore wat later as die menslike beskawing bekend sou staan. Die geboorte van die beskawing, doen Sylvia Crowe aan die hand, kan beskryf word as die oomblik waarop die mens die eerste keer bewus word van sy omgewing, en dit kan alleen groei deur die vrystelling van surplus-energie wat aan die mens tyd laat om te dink en om te skep (7: 538). Grootliks dieselfde gedagte word uitgespreek deur Hyams waar hy met kursivering beklemtoon dat die eerste stap tot beskawing bodemontginning is $(5: 31)$.

Ongelukkig tref dit ook so dat, wanneer die mens hierdie sprong maak, sy rol teenoor die omgewing ingrypend veran. der. Tot in hierdie stadium het hy die landskap aanvaar as sy natuurlike omgewing: hy het geleef van die voedsel wat sy omgewing oplewer nes die wild, en as die droogtes of plae verwoesting in die omgewing aangerig het, het sy getalle nes dié van die ander bewoners van die natuurlike omgewing gekrimp. Sy invloed op sy omgewing was nie groter as dié van ander lede van die biologiese gemeenskap nie, en hy was onderhewig aan dieselfde beheermaatreëls van die omgewing as die ander lede daarvan. Sodra die mens egter begin om sy omgewing aktief te ontgin om die surplus-energie vry te stel wat aan hom die tyd sal gee om 'n beskawing te bou, eindig sy rol as lid van die natuurlandskap. Nou word hy bouer van 'n nuwe landskap, die kultuurlandskap, waarin die mens die landskap wat die natuur geskep het volgens sy eie wil wysig deur tie wild te verdryf en dit te vervang met sy eie mak diere of die natuurlike plantegroei uit te roei en sy eie gewasse in die plek daarvan te stel. Die mens het inderdaad 'n parasiet van die omgewing geword, verklaar Hyams van hierdie stadium, 
omdat hy vir hom 'n nuwe ekonomiese hulpmiddel gevind het om die omgewingsbronne te ontgin, soos bv. die pense van cliere wat plantegroei vir hom tot melk en vleis sal verwerk, of graan-grassoorte wat die grondvrugbaarheid vir hom tot graankorrels omvorm. En dit kan moontlik beskou word as die begin van die tegnologiese prosesse wat eindig in die stootskaper, die kernkragsentrale en die rekenoutomaat.

Dit beteken natuurlik nog geensins dat die mens in hierdie vroeë gedaanteverwisseling 'n kwaadaardige parasiet geword het nie; hierdie bedrywighede kan binne perke voortgesit word sonder om blywende afbreuk aan die vermoëns van die natuur te doen, net soos die vlooie op die hond eintlik lastige parasiete is maar in matige hoeveelhede nie juis kwaadaardig vir sover dit die hond aangaan nie.

Met die geboorte van die menslike beskawing het daar dus 'n nuwe soort wisselwerking tussen die mens en die omgewing begin. Die mens staan aan die een kant, begerig om sy natuurlike omgewing om te skep in 'n kultuurlandskap sodat hy sy beskawing kan uitbou. Aan die ander kant is die natuurlike omgewing van landvorms, rotse, klimaat, plantegroei en die dierelewe. Tussen hierdie twee staan die verhouding tussen die menslike bedrywighede en die natuurlike habitat - aan die een kant die mens wat sy behoeftes en begeertes wil bevredig en in die proses die omgewing wil verander, en aan die ander kant die omgewing en sy natuurlike weerstand teen die pogings van die mens (4: 13).

Nou tref dit ook so dat, namate die mens sy beskawingspatroon verander, die eise wat hy aan die omgewing stel ook anders word. Elke beskawingspatroon stel trouens sy eie eise aan die omgewing, en vir elke kombinasie van beskauing en omgewing sal die wedersydse invloed op mekaar gevolglik ook anders wees. Huntington beskryf trouens hoe die beskawingsentrum oor ' $n$ periode van enkele duisende jare verskuif het van Egipte en Babilonië na Kreta, Sirië en Assirië, daarna na Griekeland en Rome, toe na Parys en Wenen, en uiteindelik na Londen, Amsterdam en Berlyn - steeds noordwaarts oor ' $n$ afstand van meer as 2,000 myl. Dit, sê hy, het geskied omdat die optimum klimaat vir menslike bedrywighede wissel van beskawing tot beskawing; en namate landboutegnieke verbeter, kleding doeltreffender word, behuising moderner gemaak word 
en kunsmatige verhittingsprosesse vervolmaak word, word dit steeds moontliker vir die mens om te kan beweeg na klimaatsomstandighede wat gunstiger is vir geestesaktiwiteite en beskawingsuitbouing ( $8: 208)$. Hieruit vloei voort dat die wedersydse inwerking van beskawing en omgewing in SuidAfrika in die geval van die blanke bevolkingsdeel heel verskillend sal wees van dié van die verskillende nie-blanke bevolkingsgroepe met hul eie beskawingspatroon, en om dié rede word hierdie bespreking beperk tot slegs die blanke bevolkingsgroep en sy beskawing. Maar terselfdertyd vloei hieruit voort dat die wedersydse invloed van beskawing en omgewing aan voortdurende verandering onderhewig is soos die eise van die beskawing verander en daardie eise verandering in die omgewing aanbring. Invloede wat vyftig jaar gelede in een rigting gewerk het, kan vandag moontlik heeltemal in die teenoorgestelde rigting krag uitoefen.

Indien ons aanvaar dat hierdie wisselwerking tussen beskawing en omgewing bestaan - en ek dink nie dat iemand sal waag om dit te betwis nie - aanvaar ons terselfdertyd dat enige beskawing ook gedeeltelik ' $n$ produk is van die omgewing waarin dit ontstaan het. Die wedersydse invloed kon immers nie net van die een kant af gekom het nie. Met die koms van die blanke na Suid-Afrika het ons dus die posisie dat 'n beskawingspatroon hierheen gebring is wat nie die resultaat was van wedersydse beïnvloeding tussen 'n Suid-Afrikaanse bevolkingsgroep en 'n Suid-Afrikaanse omgewing nie. Hoewel die beskawingspatroon eie was aan die blanke bevolkingsgroep, was dit vreemd vir die Suid-Afrikaanse omgewing waarin dit oorgeplant is. Laat my dit tussen hakies hier net duidelik stel dat waar ek hier van omgewing praat, ek dit in die breedste sin bedoel. Vir die blankes wat na Suid-Afrika gekom het en wat nie biologies, sosiaal of andersins met die inheemse bevolkings geassimileer is nie, was die inheemse bevolkings in geen mindere mate ' $n$ faktor van die omgewing as bv. die suidoostewind wat Van Riebeeck se tuin verwaai het of die renoster wat Simon van der Stel bestorm het nie. Ek dink dus dat waar hier van die Suid-Afrikaanse omgewing gepraat word, die nie-blanke bevolkingsgroepe ook daarby ingesluit kan word vir sover dit die blankes betref.

Dit is na hierdie omgewing, afgeleë, vreemd en in baie op- 
sigte ongetem, dat ' $n$ beskawingspatroon van Europa af gebring is, ' $n$ beskawingspatroon wat reeds veel verder ontwikkel was as wat die nuwe landskap waarop dit oorgeplant is kenmerke van kulturele ontwikkeling gedra het. ' $n$ Mens sou inderdaad kon sê dat die natuurlandskap feitlik nog ongeskonde in SuidAfrika bestaan het en dat ' $n$ beskawing hierheen oorgebring is uit ' $n$ landstreek waar die kultuurlandskap in wisselwerking reeds so ver ontwikkel het dat die mens lank nie meer in staat was om die natuurlandskap selfs maar in sy verbeelding te rekonstrueer nie.

Dit is interessant om te kyk hoe ver dié nuwe beskawing reeds tegnologies ontwikkel was toe Van Riebeeck in 1652 hier aangekom het. Reeds in die eeu tevore het windmeulens met 10 perdekrag algemeen geword; daar was meganisering in die mynwese, hoogoonde is gebruik vir ysterverwerking en tinlae is oor yster aangebring om dit teen roes te beskerm. In die Duitse myne is trouens van vervoer oor spoorstawe gebruik gemaak.

Die tempo van die nuwe ontdekkings het in die 50 jaar voor Van Riebeeck se koms heelwat versnel. Toe die sewentiende eeu begin het, kon waterwiele 20 perdekrag opweik en daardie krag kon oor 'n afstand van 'n kwart myl vervoer word. ' $n$ Masjien is ontwerp om koring te saai; in 1618 is 'n ander masjien ontwerp om te ploeg, bemesting toe te dien en te saai, en in 1636 het die dorsmasjien gekom en terloops ook die vulpen. In die jaar van Van Riebeeck se landing is die lugpomp uitgevind.

Maar ook ná die stigting van die blanke nedersetting aan die Kaap gaan die tegnologiese vooruitgang wat die mens in staat stel om aspekte van sy omgewing feitlik na willekeur te omvorm, meedoënloos voort. In 1756 word sement byvoorbeeld uitgevind, en in 1774 die boormasjien. In 1831 word die oes-masjien ontwerp (9: 438) en vier dekades later word dit 'n algemene deel van die Suid-Afrikaanse toneel, nadat ds. Van Warmelo tot die oortuiging geraak het dat die verwerking van die oes 'n knelpunt vir die landbouproduksie daarstel en hy gevolglik twee dorsmasjiene in 1876 na die SuidAfrikaanse Republiek laat kom het (10: 94). Hier is dus 'n voorbeeld by uitstek van waar die tegnologiese eienskappe van die oorgeplante beskawing meegehelp het om veel hoër eise 
aan die nuwe bodem te stel as wat die geval tevore was.

Dit is met ' $n$ beskawingspatroon wat hierdie ontwikkeling en ontwikkelingsmoontlikhede in hom omgedra het dat Van Riebeeck aangekom het in 'n Afrika wat toe nog haas geen tekens van beskawing in sy landskap geken het nie. Vanselfsprekend het sterk invloede uitgegaan. Om enkeles te noem: die ligging van Suid-Afrika, maande ver verwyder van aanraking met die bakermat van sy beskawing en dit in 'n tydvak toe massamediums van gedagtewisseling nog kwalik bestaan het, moes noodwendig 'n sterk mate van isolasie meegebring het: isolasie nie net van die kant van Suid-Afrika nie, maar ook van die kant van Europa wat nie op hoogte kon bly met verwikkelinge in Suid-Afrika nie. In Europa was ingrypende woelinge in die gees van die mens aan die gang: die Franse Revolusie, die opkoms van die liberalistiese denkwyse, die materialisme en die kapitalisme - alles dinge waarvan Suid-Afrika op 'n afstand moes verneem. Maar ook in SuidAfrika was prosesse aan die gang, want 'n mens kan nie aanvaar dat die wisselwerking tussen beskawing en omgewing opgehou het in die jaar 1652 nie. Die Suid-Afrikaanse omgewing moes noodwendig invloed uitgeoefen het op die nuwe Europese beskawing in sy midde, en in daardie proses moes die beskawing wat hierheen gebring is, geleidelik 'n ander karakter aangeneem het, selfs al het die vernaamste trekke daarvan moontlik onveranderd gebly. En hiervan, moet 'n mens aanneem, het Europa weinig indien enigiets verneem. Sou dit nie dalk die begin gewees het, hierdie betreklike isolasie tussen die Europese beskawing en die stadig veranderende Suid-Afrikaans-Europese beskawing, van die spannings en oënskynlike onvermoë om mekaar te begryp wat op die oomblik tussen Suid-Afrika en die res van die Westerse wêreld heers nie? Indien ons die begrip „omgewing" só vertolk as wat ek pas hier bo verduidelik het, naamlik dat dit ook die inheemse rasse insluit, sal ek weinig aarseling hê om hierdie vraag in 'n positiewe stelling om te skep.

'n Mens het ook geen besondere verbeelding nodig om nog vele ander uitwerkings van die afgeleë ligging van Suid-Afrika raak te sien nie, maar te veel aandag daaraan sal ons te ver slegs in een besondere rigting voer. Daar was ook talryke ander omgewingsfaktore wat hul invloed in wisselwerking tussen 
omgewing en beskawing laat geld het en wat vermelding verdien.

Een sodanige faktor is die groot ruimte wat daar in SuidAfrika vir die draers van die nuwe beskawing beskikbaar was. Weens die stamoorlö̈ onder die inboorlinge was groot clele van Suid-Afrika min of meer onbevolk ten tye van die blanke intog na die binneland, en die betreklik klein groepie blankes kon hulle oor 'n uitgestrekte gebied versprei. Wat die uitwerking van hierdie bykans onbeperkte ruimte op die nuwe intrekkers en hul beskawingspatroon in Transvaal was, kon ek enkele jare gelede nagaan (11: 167). Dit het o.a. geblyk dat die groot ruimtes nie alleen die permanente vestiging van die intrekkers vertraag het nie, maar dat dit ook die vorming van 'n eenheidsgevoel in die wiele gery het, inderdaad 'n mate van antagonisme onderling verwek het wat die totstandkoming van 'n verenigde staat ernstig belemmer het. In sommige gebiede - eienaardig genoeg juis daar waar die natuurlike omgewing die moontlikheid van spoedige rykdomme vir die inwoners voorgehou het - het daar selfs ernstige morele verval ingetree, en prof. Eric Walker verklaar selfs dat die beskawingspeil van die intrekkers na Transvaal algemeen gedaal het as gevolg van die groot ruimtes wat tot hul beskikking was (12: 18).

Gelukkig was daar ander omgewingsinvloede wat perke aan die ruimte gestel het. Een sodanige faktor wat 'n „harde les oor die grense wat die natuur in Afrika vir die witman gestel het" aan die intrekkers geleer het, was koors (13: 276). Dit het nie alleen die moontlike gebied vir bewoning deur blankes in Transvaal beperk tot die gebied besuide die Limpopo en ten weste van die oostelike laeveld nie, dit het hom ook daarvan weerhou om sy jagtogte dwarsdeur die jaar voort te sit en dit het die belangrike uitwerking gehad dat dit die blanke intrekkers na Transvaal doeltreffend van verbinding met die see afgesny het en hul isolasie dus vererger het (11: 185). 'n Ander omgewingsfaktor wat die ruimte beperk het, was die tsetsevlieg, wat sy uitwerking veral laat geld het op die mens se veebesit. Dit het enersyds die ruimte wat deur veeboere benut kon word aan bande gelê en dit het andersyds voorkom dat die intrekkers die Limpopo sou oorsteek en dieper die binneland van Afrika sou ingaan. Terselfdertyd 
het dit minstens 'n ruk lank voorkom dat Transvaal doeltreffende verbinding met die see by Lourenco Marques sou kry, en ook dit het tot die isolasie bygedra.

En só sou 'n mens etlike ander omgewingsinvloede kon noem wat hulle op die ontplooiing van die beskawingspatroon in Transvaal laat geld het, soos die dorsland in die weste, die perdesiekte in die somers wat militêre optrede in daardie seisoen bemoeilik het, sprinkane wat die ontstaan van 'n lewenskragtige akkerboubevolking amper onmoontlik gemaak het, en nog veel meer. Dit sou egter geskied sonder om veel nuwe lig op die probleem te werp, omdat hul uitwerking almal min of meer negatief was. Een besondere omgewingsfaktor verdien egter spesiale aandag: die groot wildrykdom van Suid-Afrika. Vir die blankes was die uitnodiging wat die wild gebied het feitlik onweerstaanbaar. Gedurende die winters het Transvalers hul plase in die hoër liggende gebiede eenvoudig verlaat en na die laeveld gegaan om aan die jag deel te neem, juis in die seisoen waarin die koors geen bedreiging in die laeveld vorm nie. Die koeler winterklimaat in die andersins warm laeveld het nie alleen gunstige toestande vir die maak van biltong en ander produkte van die jag geskep nie, dit het ook gunstige toestande geskep vir winterweiding vir die vee. Die seisoenstrek het dus 'n ontsaglike omvang aangeneem. Maar vir die Transvalers was dit nie net 'n geval van plesiernajaging nie: voordat die land vir die veeboerdery oopgemaak kon word, moes die leeus eers verdryf word, en leeujag is ook beskou as ' $n$ openbare diens. Ook die jag op ander wild is in sekere mate só beskou: reeds vroeg het dit geblyk dat wild as gasheer vir die tsetsevlieg dien en dat as die wild uitgeroei is, die tsetsevlieg ook verdwyn. Op dié uyse kon dele van Transvaal wat aanvanklik nie vir die veeboerdery geskik was nie, uiteindelik tog daarvoor oopgemaak word deur middel van die jag.

Al hierdie oorwegings het gemaak dat die boere van Transvaal gedurende die winters etlike maande lank hul plase verlaat het en in die laeveld gaan kampeer het. 'n Mens kan jou die invloed hiervan op die beskawingspatroon maklik voorstel. In die winters was die owerheid militêr magteloos, en dit is openlik erken: die weerbare manne was in die laeveld besig met die jag. En in die somers, terloops, was dit weer die perde- 
siekte wat paal en perk aan militêre bedrywighede gestel het. Maar nie net die strydvermoë is in die winters verlam nie. Die kerklike lewe, die bietjie onderwysgeleentheid wat daar bestaan het, die verbetering van die plase - kortom, die meeste aspekte van die kulturele lewe het in die jagtydperk feitlik tot stilstand gekon. Noodwendig het dit die ontplooiing van die beskawingspatroon vertraag.

Vir sover bekend, is daar nog nie ' $n$ instrument ontwerp waarmee 'n saamgestelde en abstrakte begrip soos „volkskarakter" met eksaktheid gemeet kan word nie - veral nie die volkskarakter van mense wat lank reeds tot die vadere vergader is nie. Bespiegelinge hieroor sal dus waarskynlik nooit verder as die vlak van die hipotese gevoer kan word nie. Maar as dit is soos Hyans beweer, dat die karakters van mense veel buigbaarder is as hul spiere, en 'n mens sou die karakter kon bepaal van die blanke aankomelinge in Suid-Afrika voordat die Suid-Afrikaanse omgewing hulle beïnvloed het en weer nadat hulle oor die land versprei het met sy wild, sy ruimtes, sy hindernisse en sy moontlikhede, is dit denkbaar dat sekere belangrike verskille opgemerk sal word. Sou die ruimtes waarin die een mens kwalik van die bestaan van sy naaste buurman bewus was, die aanloklike jagveld wat mense daartoe bring om huis en haard maande lank te verlaat om in betreklike ongebondenheid te gaan ontspan, die interne isolasie wat die bande tussen owerheid en onderdaan tot breekpunt toe gespan het - sou dit nie alles kon bydra tot ' $n$ sterk individualisme, 'n onafhanklikheidsin, ' $n$ afkeurige neiging teenoor diktate van die owerheid en dies meer nie? En is dit nie juis sulke eienskappe wat gestalte gee aan die beskawingspatroon wat 'n groep vir homself skep nie - skep as gevolg van die wedersydse inwerking van omgewing op mekaar nie? Maar soos ek gewaarsku het, ons bevind ons hier op die terrein van die hipotese.

Die okkuperingsfase wat tot dusver behandel is, het hom afgespeel in 'n tydperk toe die natuurlandskap nog betreklik ongeskonde en sterk was, waarskynlik oorheersend in die verhouding tussen mens en omgewing. Die mensegetalle was te gering om binne korte tyd ingrypende invloed op die natuur uit te oefen selfs met die destyds bestaande en beskikbare tegnologiese hulpmiddels; aan die ander kant was die natuur 
soms byna oorweldigend in die moontlikhede wat hy die mens aangebied het. Dit wil amper lyk asof die lang tydperk van wisselwerking tussen omgewing en beskawing wat hom vroeër oor 'n tydperk van eeue op Europese bodem afgespeel het, hom hier in die nuwe omgewing weer in die kleine moes afspeel, sy dit in soveel korter tyd, om die gaping in die ontwikkeling van landskap en beskawing te vernou. Weliswaar was die benadering van die mens teenoor die natuur in hierdie stadium wat Sylvia Crowe negatief noem: die landskap is beskou as 'n skuur wat geplunder moes word, 'n vyand wat onderwerp moes word (7: 538). Maar die wisselwerking tussen beskawing en omgewing was volstoom aan die gang en die mens was doelbew'us besig met die omskepping van die natuurlandskap in 'n kultuurlandskap. Nou, van agterna besien, verbaas dit ons as ons let op die kort tydjie wat so min mense nodig gehad het om hul doel te verwesenlik.

Dit bring ons by die volgende fase: die tydvak waarin die mens die oorhand oor sy natuurlike omgewing, of minstens sekere belangrike aspekte daarvan, begin kry. $\mathrm{Hy}$ plaas sy eie vee in die plek van die wild wat die natuur daar gestel het, hy brand die vlaktes af om sy weiding te reguleer, hy ploeg groot stukke van die natuurlike plantegroei om en sit sy eie gewasse in die plek daarvan, en hy tem die riviere met sy betonwalle en uitkeervore. Die mens met sy tegnologiese vernuf bring ingrypende veranderinge aan in die landskap: hy maak van die natuurlandskap 'n kultuurlandskap. Maar dit, let wel, geskied in Suid-Afrika deur die dade van beskaafde aankomelinge van elders, die draers van 'n beskawingspatroon wat die resultaat is van die wedersydse inwerking op mekaar van die mens en ' $n$ ander omgewing. Die mens tree in sy nuwe SuidAfrikaanse omgewing dus op sonder die voordeel van eeuelange ervaring van aksie en reaksie soos dit tot uiting kom in die wisselwerking waaruit uiteindelik sowel die beskawingspatroon as die natuurlandskap gevorm word. Hy tree ook op in 'n tydvak waarin dit nie langer die handgedrewe klip-, brons- of ysterwerktuig is wat moeisaam brokkie vir brokkie verandering in die natuurlandskap aanbring teen 'n tempo wat regstelling maklik maak as uit die natuur se reaksie ontdek moet word dat 'n fout begaan is nie. Nou beskik hy oor die ysterploeg wat morge grond in een seisoen kan omkeer, die koeël- 
geweer wat kwalik enige vernuf van die jagter vereis om wild binne trefafstand te kry, in latere tye selfs die trekker en stootskraper wat sonder die vermoë om te dink hul eie doodse landskap van gruis en gebreekte klip kan skep, insekdoders wat miljoene insekte met slegs een bespuiting kan uitwis, sement wat riviere kan laat staan en talryke ander wapens van die wetenskap. Die omvorming van die landskap geskied teen 'n tempo en op 'n skaal wat regstelling bykans onmoontlik maak as daar later uit die reaksie van die omgewing gevind sou word dat 'n bepaalde manier van optrede 'n onverwags skadelike versteuring in die balans van die natuur veroorsaak het. En juis omdat die beskawingspatroon vir 'n groot gedeelte nie die resultaat is van langdurige wisselwerking tussen die mens en hierdie besondere omgewing nie, is die mens veelal onkundig oor die moontlike reaksie van die omgewing op die dade wat sy beskawingspatroon van hom eis. Hy tas as 't ware in die duister rond, en hoop dat as dit sleg gaan, dit nie te erg sal wees nie.

Is dit toevallig dat, as in die bewaringsletterkunde geskryf word oor gronderosie wat die resultaat is van menslike misbruik van die bodem, daar hoofsaaklik verwys word na drie gebiede: die Verenigde State, Australië en Suid-Afrika - juis dié gebiede by uitstek waar die Westerse beskawing min of meer gelyktydig oorgeplant is op nuwe bodems wat tot in daardie stadium geen rol gehad het in die wisselwerking wat gestalte aan die beskawing gegee het nie? Is daar nie dalk 'n verwantskap nie - die vergelykbare reaksie van drie bodems wat die eise nie kon dra van 'n beskawingspatroon wat op 'n ander bodem ontstaan het nie?

Want let maar op wat die invloed van ons beskawingspatroon op die geografiese omgewing was. Deur die versteuring van die natuurlike plantegroei, of deur die oormatige beweiding daarvan of deur die totale uitwissing daarvan deur middel van die ploeg, is die woestyn in Suid-Afrika uit die weste besig om steeds verder en verder ooswaarts in te dring - en dit kan regstreeks toegeskryf word aan die wyse waarop die mens die bodem gebruik. Klowe wat 'n eeu gelede dig met bosse begroei was, is kaal gestroop. Grasvelde op die berge het totaal verdwyn nadat die ploeg die aarde omgekeer het, en in die plek daarvan is vandag kaal rotsplate. Dongas ontsier 
heuwelhange, en die riviere is rooi gekleur deur die $400 \mathrm{mil}$ joen ton grond wat jaarliks daarin afspoel na die see (14: 7). En hierdie veranderinge het sienderoë plaasgevind binne die leeftyd van die afgelope geslag of twee $(15,16)$.

Noudat ' $n$ tydvak betree is waarin die draers van die blanke beskawingspatroon in Suid-Afrika deur hul tegnologiese ontwikkeling en deur hul getalle in staat is om bepaalde aspekte van die natuur te oorheers en na willekeur te vervorm, wil dit lyk asof ons nie geleer het om 'n beskawingspatroon waarvan die wesenskenmerke van oorsee kom, in weldadige wisselwerking aan te pas by 'n bodem wat nie kon bydra tot die basiese vorming van dié beskawingspatroon nie. Dit wil voorkom asof die eise van ons beskawingspatroon, of minstens dan sommige eise daarvan, veroorsaak het dat ons in die woorde van Sylvia Crowe teer op die landskap se kapitaal, dit beroof van sy bome, sy vrugbaarheid en sy water (7:538).

Die kultuurlandskap is die resultaat van drie dinge: die menslike bedrywighede soos dit georganiseer is vir die produksie van die goedere wat die mens begeer, tweedens die komplekse natuurlike omgewing wat die mens vir hierdie strewe aanwend en wysig, en wat op sy beurt weer die menslike bedrywighede beinvloed, en derdens die tydsduur waaroorheen hierdie prosesse aan die gang was, met inagneming van die beskawingspeil van die betrokke mensegroep en die tegnologiese hulpmiddele wat hulle tot hul beskikking het. As ons die aangeleentheid só beskou, kan moontlik aangevoer word dat die blanke Suid-Afrikaner nog nie voldoende tyd gehad het om die bronne van die menslike kennis ekonomies op die landskap toe te pas nie. In sy huidige stadium is hy dus nog 'n parasiet op die bodem - 'n kwaadaardige parasiet - maar na verloop van tyd kan hy, as hy hom daarop toespits, sy kwaadaardigheid verloor.

Maar dit kan ook wees dat daar aspekte van ons beskawingspatroon is wat nooit met die bodem versoen sal kan word nie - aspekte wat, so lank hulle bestaan, blywend aanleiding sal wees tot die wanbalans in die verhouding tussen mens'en bodem. Sylvia Crowe noem enkele sodanige aspekte by die naam: bevolkingsdruk op beperkte oppervlaktes, inhaligheid, die verafgoding van die winsmotief, die geloof dat spoed, masjiene en massaproduksie in hulself goed is eerder as dat 
hulle dienaars van die mensheid sal wees. Al hierdie tekortkominge in die Westerse beskawing - wat helaas ook hier by ons almal oorbekend is - is oorsake van ontsierings in die landskap, sê sy (7: 541). En indien dit so is, moet die SuidAfrikaner homself afvra of die omgewing met sy woestynvorming, sy erosieslote en sy kaal berghellings nie dalk in hierdie proses van wisselwerking vandag besig is om druk op ons beskawingspatroon uit te oefen sodat hierdie ongewenste eienskappe sal verdwyn nie.

U sien dus dat daar geen sprake kan wees van 'n beskouing van geografiese invloede op die beskawingspatroon sonder om terselfdertyd die invloed van die beskawingspatroon op die geografiese omgewing te ondersoek nie. Wanneer die een verander, verander ook die ander in hierdie proses van nimmereindigende wisselwerking, en omdat nog die beskawingspatroon nòg die omgewing staties bly, verander die wedersydse beïnvloeding ook voortdurend. Ons staan in 1966 nie aan die begin van ons beskawingsreis nie en ook nie aan die einde daarvan nie. Ons is soos die reisiger wat halfpad op sy lang tog 'n oomblikkie tot stilstand gekom het om te rus. En die beskawing wat ons met ons saamgebring het, is nie meer die Europese beskawing wat reeds drie eeue lank die invloed in wisselwerking ondergaan van 'n Suid-Afrikaanse omgewing.

Maar hier waar ons langs die pad rus, hou die reis nie op nie: ons moet verder. Die wisselwerking tussen beskawing en bodem - die verminkte bodem wat daar op die oomblik is in die plek van die natuurlandskap waarmee ons begin het - sal voortgaan, ook tot in die verre toekoms. En dit laat die ernstige vraag ontstaan of 'n beskawingspatroon kan gedy wanneer dit in so ' $n$ noue wisselwerking verkeer met ' $n$ om. gewing waarop die tekens van agteruitgang onmiskenhaar blyk. Kan ' $n$ beskawing voortbestaan tensy dit die kapitaal wat dit uit die bodem geneem het, terug betaal, tensy dit leer om te lewe op die inkomste wat verkry word uit vernaamlik die hernieubare hulpbronne van die omgewing? Crowe werp 'n helder lig op hierdie aangeleentheid waar sy sê: ,As hierdie huidige beskawing nie sterf nie, sal dit wees omdat dit 'n metode gevind het om 'n nuwe ekologie te skep wat die voortbrengsels van die menslike vernuf en brein kombineer met 
die ekologie van die organiese natuur, en omdat dit geleer het om hieruit 'n nuwe landskap te vorm waarin mense kan fungeer, nie slegs as ekonomiese eenhede nie, maar as mense" (7: 544).

En dit, dink ek, behoort vir ons as reisigers wat rus langs dic pad, die weg verder vorentoe uit te stippel. As ons wil verseker dat dic beste kenmerke van ons beskawing op die Suid-Afrikaanse bodem moet voortbestaan as resultaat van 'n weldadige wisselwerking tussen beskawing en omgewing, moet ons in die eerste plaas sowel ons beskawing as ons bodem onder die soeklig neem. Ons moet onsself afvra of daar nie kenmerke in uns beskawingspatroon is, miskien minder gewenste kenmerke soos die inhaligheid en onbeteuelde rykwordingsdrang waarna reeds verwys is, wat nie versoenbaar is met die vermoëns van die bodem wat daardie beskawing tot in lengte van dae moet voed nie. Ons moet aan die ander kant volledige helderheid verkry oor die oogmerke wat ons met ons beskawingspatroon nastreef, en dan ons uiterste vernuf gebruik om die bodem só om te vorm of te herstel dat daardie ideale verwesenlik kan word. Want die ontdekkings van die menslike brein het hom met 'n nuwe mag oor die organiese landskap beklee - 'n mag wat hy gebruik, en waarvoor hy volle verantwoordelikheid moet aanvaar.

Vir my wil dit voorkom asof die oplossing gesoek moet word in 'n reeks ewewigte: ewewig eerstens in die omgewing, dit wil sê die herstel van die balans tussen die natuur en die bedrywighede van die mens; tweedens ewewig in die ekonomiese bedrywighede van die mens, d.w.s. balans tussen die nywerheid en die landbou; en laastens ewewig in die getalsverhoudings, d.w.s. balans tussen die getal mense op 'n bepaalde bodem en die vermoëns van daardie bodem. Daar is onheilspellende tekens dat die stygende mensegetalle handuitruk, nie net meer in gelokaliseerde gebiede nie maar oor die ganse aardbol.

Maar wat ook al die oplossing vir die probleem mag wees, dit is van die uiterste belang dat ons onophoudelik daarna sal soek totdat ons dit gevind het. Dan bly daar oor die uitdaging van die toepassing daarvan, die spoedige toepassing, omdat die uur laat is en veel langer uitstel die latente mag van die natuur om van mishandeling te herstel, kan oorskry. As dit 
gebeur, bly vir ons beskawing die lot oor wat Mesopotamië getref het - verdwyning in 'n woestyn van sand. Om dit te voorkom, moet ons die landskap positief benader, dit aanvaar as 'n organisme waarvan die mense deel is, die enigste denkende deel, sodat die landskap iets sal word wat gemanipuleer en versorg word soos wat die mens sy eie liggaam manipuleer en versorg, soos Crowe dit stel (7: 538). Dalk sal dit beteken dat ons in dié proses tevrede sal moet wees om effens minder aardse skatte te vergader en dat ons effens minder blink teenoor andere sal vertoon. Maar alleen dán sal ons ons as volk waarlik ryk kan noem en 'n ryke erfenis aan toekomstige geslagte kan nalaat, as ons die geheim gevind het van 'n ureldadige invloed wedersyds tussen ons omgewing en die patroon van die beskawing waarvan ons feitlik die enigste draers is wat nog oorbly in Afrika. Tot op die huidige het ons nog nie daarin geslaag om dié aanpassing te doen nie, en solank ons dit nie gedoen het nie, moet ons steeds die invloed vrees wat miskien eendag op ons beskawingspatroon uitgeoefen kan word deur 'n omgewing wat ons in ons onkunde omgeskep het tot 'n monster wat geen beskawing duld nie.

F. J. Potgieter.

1. E. Demolins: Essai de géograpie sosiale, aangehaal deur George Tatham in Geography in the Twentieth Century, p. 15.

2. A. J. Toynbee: A Study of History, pt. 1, Abridgement by D. C. Somervell.

3. John Phillips: Argiculture and Ecology in Africa.

4. P. W. Ryan: Man's Adaptation of Nature.

5. Edward Hyams: Soil and Civilization.

6. Lewis Mumford: The City in History.

7. Sylvia Crowe: Civilization and Landscape (Smithsonian Institution Report for the year ended June 30, 1962).

8. E. Huntingon: The March of Civilization, opgeneem in S. van Valken burg en C. C. Held: Europe

9. Lewis Mumford: Technics and Civilization.

10. G. S. Preller: Ons Goud Roman.

11. F. J. Potgieter: Die Vestiging van die Blankes in Transvaal (18371886) (Argiefjaarboek, Deel II, 21e jaargang).

12. E. A. Walker: The Frontier Tradition in South Africa.

13. P. Serton: Die aardrykskundige grondslag van ons geskiedenis, opgeneem in S. F. N. Gie: Geskiedenis van Suid-Afrika.

14. D. C. Midgley: Taming or Wild Rivers - Inaugural Lecture, University of the Witwatersrand.

15. Verslag van die Woestynindringingskommissie (1952).

16. Verslag van die Droogte-ondersoekkommissie (1923). 